\title{
Seminar dan Workshop Internet of Things guna merealisasikan Pembelajaran Industri 4.0 di Sekolah dan Masyarakat
}

\author{
Lukman Rosyidi ${ }^{1)}$ | Muh Syaiful Romadhon ${ }^{2)}$ \\ ${ }^{1,2)}$ STT Terpadu Nurul Fikri \\ lukman@nurulfikri.ac.id |syaiful@nurulfikri.ac.id
}

\begin{abstract}
Abstrak: Revolusi Industri 4.0 telah membawa perubahan pada dunia. Berbagai teknologi baru seperti cloud computing, Internet of things, Big Data, artificial intelligence, dan advance robotics telah dan akan mengubah cara manusia dalam bekerja dan menjalankan kehidupan. Internet of things, atau dikenal juga dengan IoT, merupakan sebuah teknologi yang bertujuan untuk memperluas manfaat dari konektivitas internet yang tersambung secara terus-menerus. Saat ini, Internet of things(IoT) telah secara luas digunakan untuk meningkatkan kualitas kehidupan manusia. Kasus aplikasi IoT yang paling umum adalah mengumpulkan informasi tentang suatu obyek secara real time untuk kegiatan pemantauan dan analisis data. Informasi ini akan berguna untuk memberikan layanan yang lebih baik atau meningkatkan produktivita. Kegiatan pengabdian kepada masyarakat ini bertujuan untuk menyebarluaskan pengetahuan pemrograman IoT untuk pemula, sebagai dasar untuk penguasaan penerapan IoT dan pembelajaran IoT pada tingkatan berikutnya. Antusiasme dan respon yang diberikan para peserta juga sangat bagus. Rata-rata peserta memberikan jawaban sangat puas dengan presentase sebesr $71 \%$. Hanya $3 \%$ yang menjawab cukup puas sedangkan sisanya menjawab puas. Seluruh peserta sama sekali tidak ada yang menjawab puas dan kurang puas.
\end{abstract}

Kata Kunci: Internet of things, Pembelajaran, Industri 4.0, Mahasiswa, Pengabdian Mayarakat

\begin{abstract}
Pendahuluan
Revolusi Industri 4.0 telah membawa perubahan pada dunia(Tarantang, Awwaliyah, Astuti, \& Munawaroh, 2019). Berbagai teknologi baru seperti cloud computing, Internet of things, Big Data, artificial intelligence, Blockchain dan advance robotics telah dan akan mengubah cara manusia dalam bekerja dan menjalankan kehidupan(Rosyidi, Maryanto, \& Romadhon, 2019). Internet of things atau dikenal juga dengan IoT, merupakan sebuah teknologi yang bertujuan untuk memperluas manfaat dari konektivitas internet yang tersambung secara terus-menerus(Hardani \& Hayat, 2020). Adapun manfaat yang diberikan seperti berbagi data, kontrol jarak jauh, dan sebagainya, yang semuanya tersambung ke jaringan global dengan mendayagunakan sensor yang tertanam dan selalu aktif. Pada dasarnya, IoT mengacu pada benda yang dapat diidentifikasikan secara unik sebagai representasi virtual dalam struktur sistem berbasis internet(Dhika \& Destiawati, 2018).
\end{abstract}

Dalam praktiknya, IoT tidak lepas dari pembuatan dan pemrograman perangkat-perangkat yang mendukung sistem tersebut agar dapat berjalan dan saling berhubungan(Hardani \& Hayat, 2020). Dengan program tersebut, dapat dipastikan bahwa adanya komunikasi antar perangkat-perangkat pendukung IoT yang terjadi secara intensif, dengan sesama perangkat itu sendiri ataupun dengan perangkat luar. Penerapan IoT tersebut kemudian membuka solusi-solusi baru yang dituangkan dalam konsep smart city, smart health, smart transportation, smart building, smart farming, dan sebagainya(Kristianti, 2019). 
Penguasaan masyarakat Indonesia terkait IoT masih sangat minim, padahal kemampuan menerapkan IoT akan sangat bermanfaat untuk meningkatkan produktivitas dan menyelesaikan berbagai permasalahan di masyarakat(Kadarina \& Priambodo, 2018). Kegiatan pengabdian kepada masyarakat ini bertujuan untuk menyebarluaskan pengetahuan pemrograman IoT untuk pemula, sebagai dasar untuk penguasaan penerapan IoT dan pembelajaran IoT pada tingkatan berikutnya..

Sekolah Tinggi Teknologi Terpadu Nurul Fikri (STT-NF) sebagai lembaga pengembang ilmu dapat memiliki peranan penting dalam membantu, baik kepada para guru maupun siswa, dalam memahami dan mempersiapkan diri menghadapi era Revolusi Industri 4.0. Kegiatan pengabdian kepada masyarakat merupakan salah satu kegiatan yang menjadi sarana guna kontribusi perguruan tinggi kepada masyarakat, termasuk dalam memberikan pengetahuan dan keterampilan terkait Internet of things sebagai salah satu teknologi Industri 4.0.

\section{Realisasi Kegiatan}

Saat ini, Internet of things (IoT) telah secara luas digunakan untuk meningkatkan kualitas kehidupan manusia. Kasus aplikasi IoT yang paling umum adalah mengumpulkan informasi tentang suatu obyek secara real time untuk kegiatan pemantauan dan analisis data. Informasi ini akan berguna untuk memberikan layanan yang lebih baik atau meningkatkan produktivitas(Hasiholan, Primananda, \& Amron, 2018).

Dalam praktik di lapangan, penguasaan teknologi IoT oleh sumber daya manusia di Indonesia masih menghadapi banyak kendala. Beberapa kendala tersebut adalah:

1. Minimnya informasi dan sosialisasi tentang pemanfaatan teknologi IoT

2. Kurangnya tenaga ahli dalam memberikan transfer pengetahuan kepada masyarakat tentang teknologi IoT ini.

3. Kurangnya ketersediaan perangkat belajar IoT yang bisa didapatkan dengan mudah Dengan demikian diperlukan diadakan upaya-upaya yang lebih masif dalam mengatasi kendala tersebut sehingga teknologi IoT bisa dikuasai dan dimanfaatkan oleh masyarakat Indonesia.

Inisiatif pembelajaran IoT tidak terlepas dari ekosistem yang harus ada dan yang harus diciptakan guna keberhasilan pembelajaran. Pemerintah dalam hal ini Kementerian Pendidikan dan Kebudayaan (Kemendikbud) berwenang menetapkan kurikulum yang diimplementasikan dalam mata pelajaran yang diberikan kepada siswa. Dalam hal ini, Kemendikbud hingga kini belum menetapkan suatu program terkait pembelajaran Industri 4.0 sedangkan sekolah telah memiliki inisiatif untuk menjadikan pembelajaran tersebut sebagai kebutuhan dan keunggulan(Dhika \& Destiawati, 2018).

Guna merealisasikan pembelajaran Industri 4.0 di sekolah dan masyarakat, maka diusulkan suatu program pengabdian masyarakat melalui bentuk kegiatan sebagai berikut.

1. Kegiatan seminar, yaitu pemaparan dan diskusi tentang pengenalan dan pemanfaatan teknologi IoT. Seminar dilakukan untuk memberikan pengetahuan tentang materi dan metode pembuatan IoT. Seminar diberikan oleh pelaksana pengabdian masyarakat dari STT NF dengan poin-poin materi sebagai berikut.

a. Pendahuluan Revolusi Industri 4.0

b. Pengenalan Internet of things (IoT)

c. Penjelasan dasar cara pembelajaran dan pembuatan aplikasi IoT

d. Penjelasan contoh kasus pemanfaatan IoT

Diharapkan setelah kegiatan seminar dan diskusi, para peserta mendapatkan wawasan tentang IoT dan memiliki ketertarikan terhadap pemanfaatan IoT untuk bidang masing-masing.

2. Kegiatan workshop, yaitu demo dan praktik singkat tentang pembuatan / pemanfaatan IoT. Workshop dilakukan untuk memberikan pengalaman praktik IoT kepada para peserta. 
Workshop diberikan oleh pelaksana pengabdian masyarakat dari STT NF dengan poin-poin materi sebagai berikut.
a. Pengenalan perangkat keras dan perangkat lunak bantu pembelajaran
b. Pengenalan dasar pemrograman untuk pembelajaran IoT
c. Praktik pendeskripsian kasus permasalahan aplikatif
d. Praktik pembuatan solusi IoT

Diharapkan setelah kegiatan workshop, peserta dapat memiliki keahlian dasar dalam praktik IoT dan mengembangkan untuk pemanfaatan di bidang masing-masing.

Peserta kegiatan meliputi guru, pelajar, dosen, mahasiswa, profesional dan masyarakat umum. Pelaksanaan kegiatan pengabdian masyarakat telah dilakukan pada tanggal 6 Februari 2021 melalui media virtual aplikasi Zoom Meeting.

Pelaksanaan kegiatan berjalan dengan baik. Para peserta antusias dalam diskusi dan workshop yang diberikan, dengan aktif mengajukan pertanyaan dan memberikan pendapat terkait cara memanfaatkan dan mengaplikasikan Internet of things.

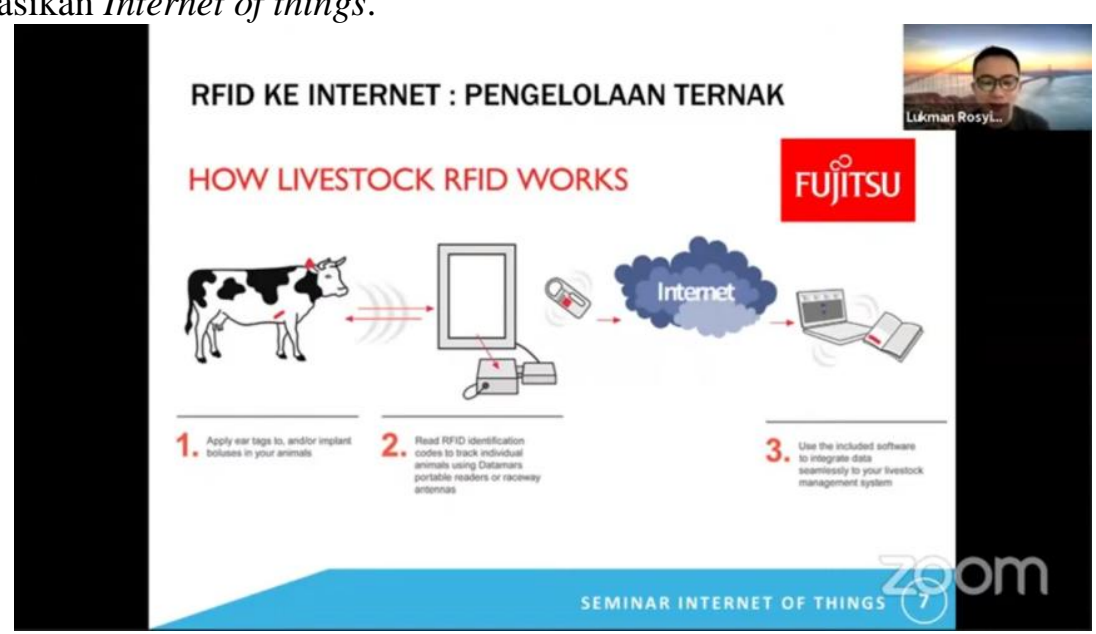

Gambar 1. Penyampaian materi Internet Of Things

\section{OUTLINE}

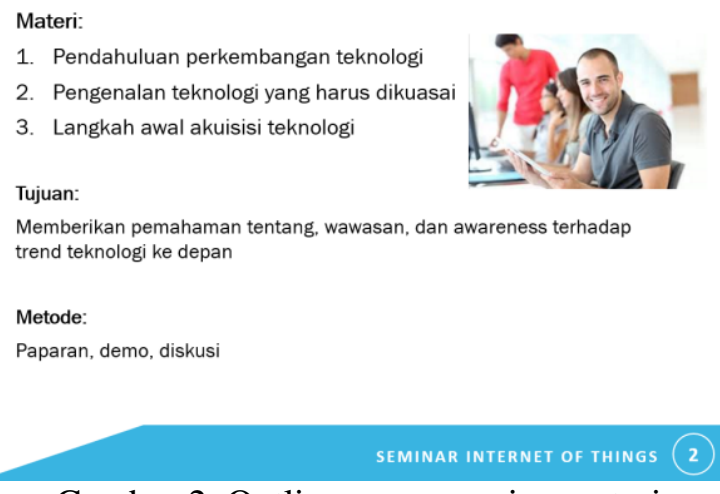

Gambar 2. Outline penyampaian materi
DEFINISI INTERNET OF THINGS

Internet of Things (IoT) is a global network of various physical devices such as sensors, actuators, and mobile devices, which are connected to the internet and then do the collection, exchange and processing of data. (ITU)

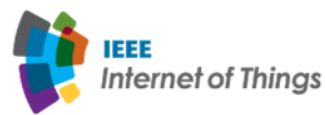

The loT envisions a complex system whose purpose is to interconnect
sensors, actuators and smart devices in such a way that makes them
intelligent, programmable and more capable interacting with humans by
providing useful services. (IEEE)
SEMINAR INTERNET OF THINGS

Gambar 3. Materi Internet of Things

\section{Hasil}

Kegiatan pengabdian masyarakat yang dilaksanakan diikuti oleh berbagai macam profesi. Jumlah peserta terdaftar terdiri dari 111 orang dengan presentase 97, 3\% terdiri dari Mahasiswa. Peserta berasal dari berbagai kota seluruh di seluruh Indonesia. Adapun diagramnya dapat dilihat sebagai berikut: 
Dedikasi Sains dan Teknologi

Jurnal Pengabdian Masyarakat

Vol: 1, No: 1, Mei 2021

Doi : https://doi.org/ 10.47709/dst.v1i1.957
Submitted : 17 Mei 201

Accepted : 18 Mei 2021

Published : 18 Mei 2021
Profesi

111 responses

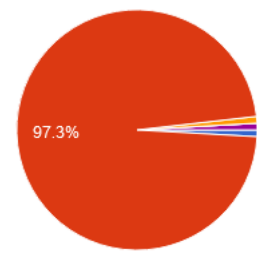

Gambar 4. Daftar peserta berdasarkan profesi

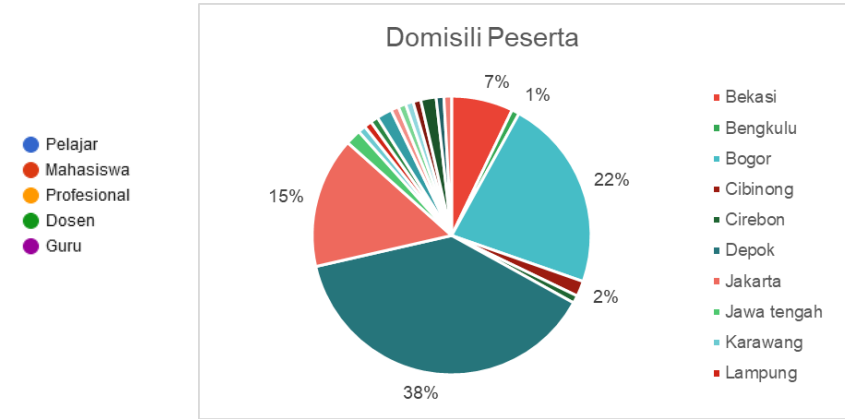

Gambar 5. Daftar Peserta berdasarkan Domisili

Berikut hasil tangkapan layer dari seluruh peserta yang hadir dan mengikuti kegiatan seminar dan workshop Internet of Things:
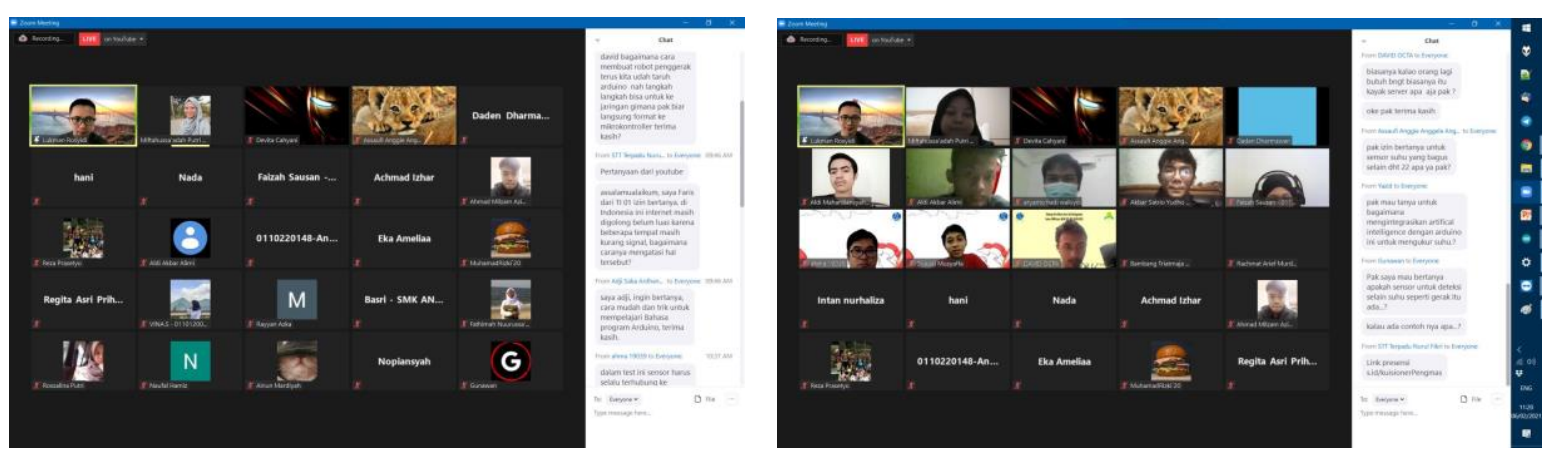

Gambar 6. Tangkapan layar peserta yang hadir
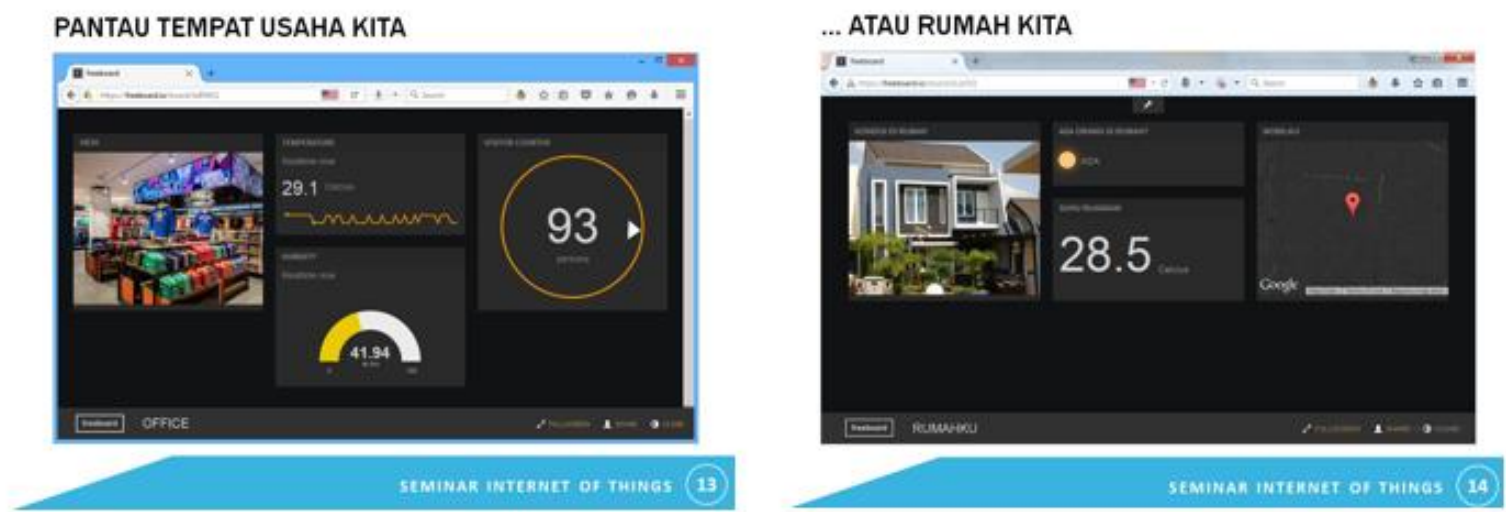

Gambar 7. Implementasi dan penerapan IoT 

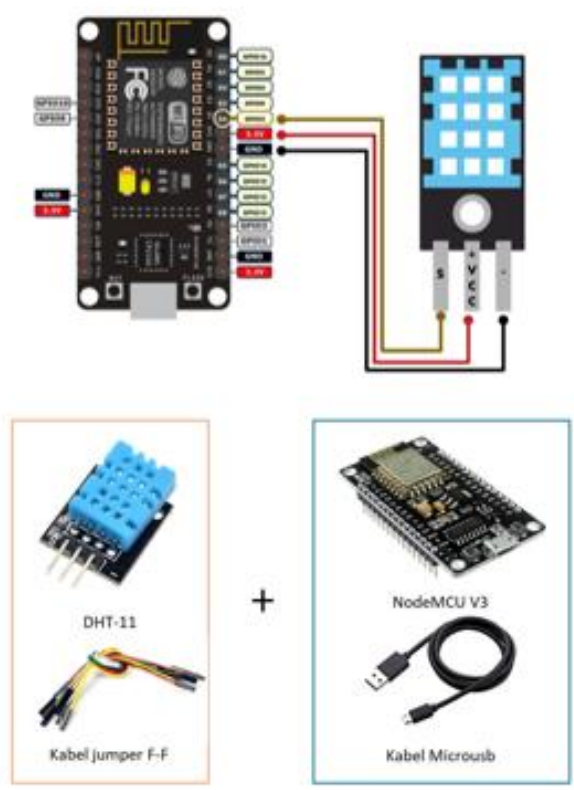
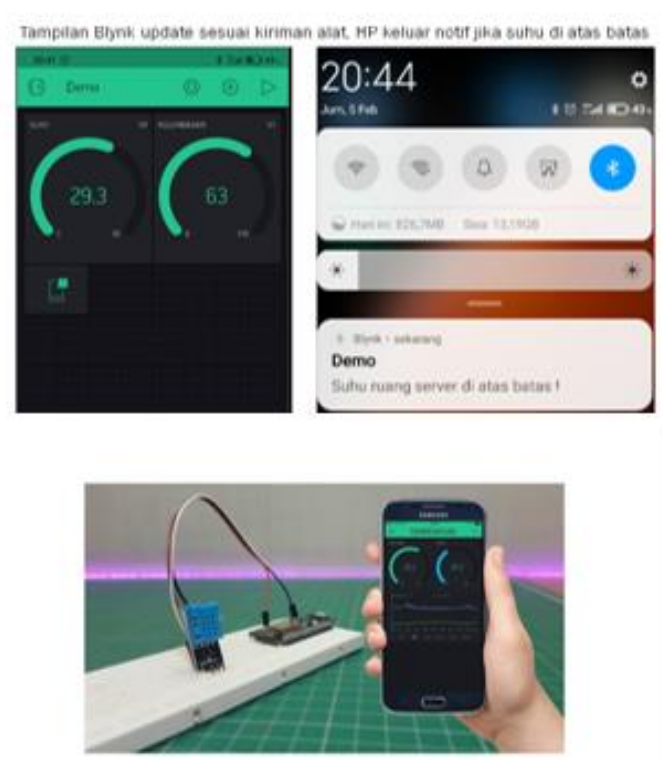

Gambar 8. Praktik dan demo implementasi IoT

Pada kegiatan seminar dan workshop penerapan IoT, pemateri memberikan kuesioner untuk dijawab oleh seluruh peserta yang hadir. Lembar kuesioner berisi enam pertanyaan terhadap kinerja dan kepuasan selama kegiatan berlangsung. Hasil pertanyaan tersebut dijadikan sebagai media evaluasi kegiatan serta untuk memperbaiki kegiatan yang akan datang. Form kuesioner menggunakan skala Linkert bernilai 5 dengan tolak ukur sebagai berikut:

$\mathrm{SP}=$ Sangat Puas

$\mathrm{P}=$ Puas

$\mathrm{CP}=$ Cukup Puas

$\mathrm{TP}=$ Tidak Puas

STP $=$ Sangat Tidak Puas

Tabel 1. Hasil kuesioner tingkat kepuasan peserta

\begin{tabular}{|c|l|c|c|c|c|c|}
\hline No. & \multicolumn{1}{|c|}{ Pertanyaan } & STP & TP & CP & P & SP \\
\hline 1 & $\begin{array}{l}\text { Apakah Materi yang disampaikan } \\
\text { sesuai dengan Kebutuhan Peserta? }\end{array}$ & 0 & 0 & 1 & 24 & 47 \\
\hline 2 & $\begin{array}{l}\text { Apakah Pemateri menguasai Materi } \\
\text { dengan Baik? }\end{array}$ & 0 & 0 & 0 & 9 & 63 \\
\hline 3 & $\begin{array}{l}\text { Apakah Materi tersampaikan dengan } \\
\text { Baik? }\end{array}$ & 0 & 0 & 1 & 15 & 56 \\
\hline 4 & $\begin{array}{l}\text { Apakah kegiatan berlangsung } \\
\text { kondusif? }\end{array}$ & 0 & 0 & 1 & 20 & 51 \\
\hline 5 & $\begin{array}{l}\text { Apakah Materi sesuai dengan Minat } \\
\text { dan Bakat? }\end{array}$ & 0 & 1 & 9 & 31 & 31 \\
\hline 6 & $\begin{array}{l}\text { Apakah Anda merasa kegiatan yang } \\
\text { dilaksanakan memberikan Manfaat? }\end{array}$ & 0 & 0 & 1 & 13 & 58 \\
\hline
\end{tabular}




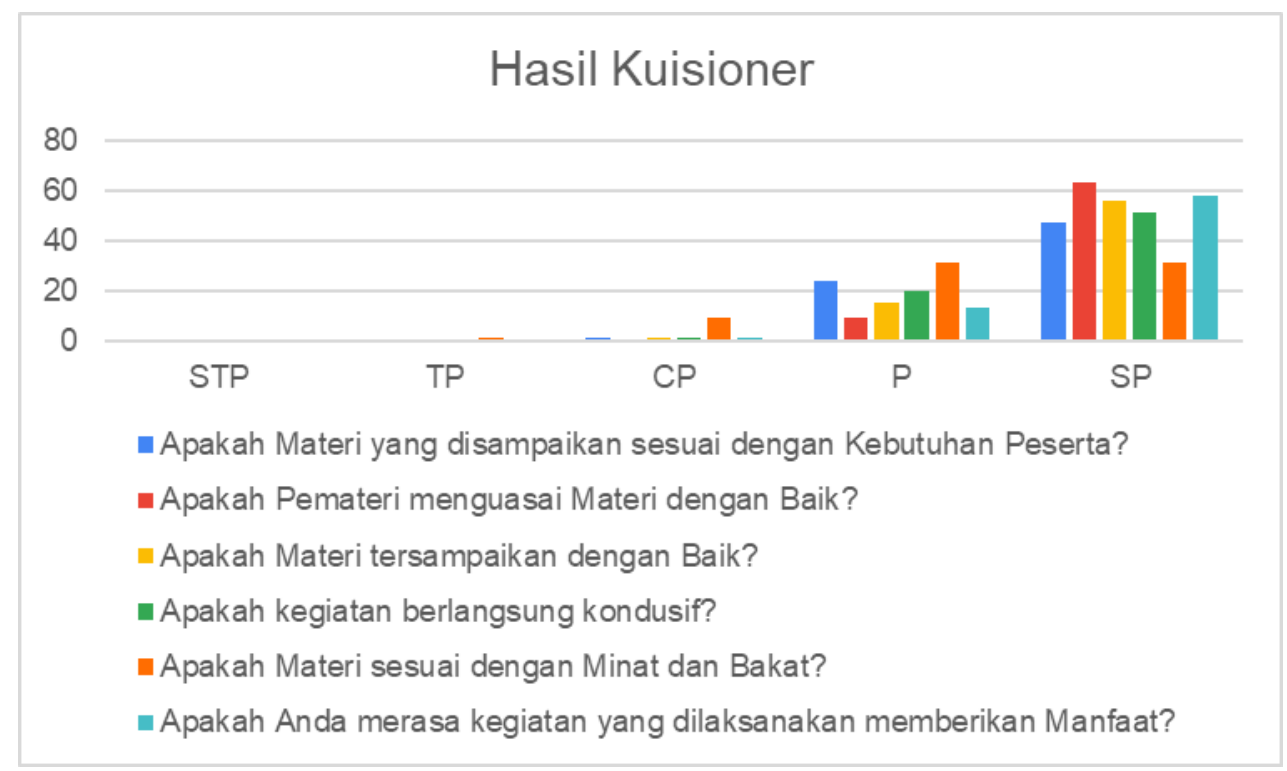

Gambar 9. Diagram hasil kuesioner peserta

Berdasarkan hasil linkert di atas maka dapat diketahui bahwa rata-rata peserta menjawab sangat puas. Sebanyak 51 orang dari keseluruhan peserta yang hadir menjawab sangat puas. Sekitar 18 peserta menjawab puas dan sisanya menjawab cukup puas. Kegiatan tersebut berjalan dengan lancara dan mendapat respon positif dari peserta.

\section{Kesimpulan}

Kegiatan pengabdian masyarakat yang dilakukan dalam bentuk seminar dan workshop ini bertujuan untuk mengenalkan IoT kepada masyarakat luas. Diharapkan masyarakat dapat memanfaatkan dengan baik pengetahuan yang telah didapatkan dan menggunakan keterampilannya. Antusiasme dan respon yang diberikan para peserta juga sangat bagus. Rata-rata peserta memberikan jawaban sangat puas dengan presentase sebesr $71 \%$. Hanya $3 \%$ yang menjawab cukup puas sedangkan sisanya menjawab puas. Seluruh peserta sama sekali tidak ada yang menjawab puas dan kurang puas. Berbagai sara dan masukan yang disampaikan, kegiatan tersebut sebaiknya dilanjutkan dengan materi yang berbeda dan lebih dalam.

\section{Daftar Pustaka}

Dhika, H., \& Destiawati, F. (2018). Penerapan Internet Of Things Dalam Ruang Kelas. (April), 110 114. https://doi.org/10.31227/osf.io/kfzv7

Hardani, D. N. K., \& Hayat, L. (2020). Penerapan Internet of Things (IoT) pada Sistem Pengendali dan Pengaman Pintu Berbasis Android. Jurnal Riset Rekayasa Elektro, 2(2). https://doi.org/10.30595/jrre.v2i2.9056

Hasiholan, C., Primananda, R., \& Amron, K. (2018). Implementasi Konsep Internet of Things pada Sistem Monitoring Banjir menggunakan Protokol MQTT. Pengembangan Teknologi Informasi Dan Ilmu Komputer, 2(12), 6128-6135.

Kadarina, T. M., \& Priambodo, R. (2018). Preliminary design of Internet of Things (IoT) application for supporting mother and child health program in Indonesia. 2017 International Conference on Broadband Communication, Wireless Sensors and Powering, BCWSP 2017, 2018-January, 1-6. https://doi.org/10.1109/BCWSP.2017.8272576

Kristianti, N. (2019). Pengaruh Internet of Things (Iot) Pada pengguna beserta resikonya. Jurnal Teknologi Informasi, 13(2), 47-53.

Rosyidi, L., Maryanto, R., \& Romadhon, M. S. (2019). Design of Blockchain Implementation for Cooperative: Indonesia Case. Proceedings of 2019 4th International Conference on Informatics 
Doi : https://doi.org/ 10.47709/dst.v1i1.957

and Computing, ICIC 2019. https://doi.org/10.1109/ICIC47613.2019.8985942

Tarantang, J., Awwaliyah, A., Astuti, M., \& Munawaroh, M. (2019). Perkembangan Sistem

Pembayaran Digital Pada Era Revolusi Industri 4.0 Di Indonesia. Jurnal Al-Qardh, 4(1), 60-75. https://doi.org/10.23971/jaq.v4i1.1442 